\title{
PENINGKATAN KEMAMPUAN GURU DALAM MENGANALISATES BUTIR SOAL SECARA KOMPUTERASI DI SMA MUHAMMADIYAH BANGKINANG
}

\author{
Defrizal Hamka*, Berry Kurnia Vilmala, Gustia Angraini \\ Pendidikan IPA, Fakultas Keguruan dan Ilmu Pendidikan \\ Universitas Muhammadiyah Riau \\ email: defrizalhamka@umri.ac.id
}

\begin{abstract}
Assessment of the learning process and assessment of learning outcomes are two very important things in education. Assessment of processes and results is a part that blends with the learning process activities. Assessment of learning processes and results is used as a reference to improve the overall learning process. One part of the assessment of learning outcomes is a test.

Schools still use multiple choice tests as a measure to determine the success of students. However, schools in this case the teachers have not been able to determine the quality and feasibility of the questions that are used well. Moreover, not many teachers understand how to analyze items in a computerized manner. Supposedly, before a double question is used as a measure of a learning process, the thing to do is analyze the problem. So that it can be determined questions that have good quality, questions that must be corrected, and which questions should be discarded. The training activity analyzed the items with computerization for the teachers at Muhammadiyah Bangkinang Senior High School to run well and smoothly. This training provides knowledge and understanding of the importance of conducting item analysis at this time.

Thus this activity is important, because the school in this case the teacher gets the knowledge and skills in analyzing question items through computarization, namely using the software Quest. So that in the future teachers will easily make improvements to the problems at school.
\end{abstract}

Keywords: Training, Analysis of Question Items, Computerization

\begin{abstract}
Abstrak
Penilaian terhadap proses pembelajaran dan penilaian terhadap hasil belajar merupakan dua hal yang sangat penting dalam pendidikan. Penilaian terhadap proses dan hasil merupakan bagian yang menyatu dengan kegiatan proses pembelajaran. Penilaian terhadap proses dan hasil pembelajaran dijadikan sebagai acuan untuk memperbaiki proses pembelajaran secara menyeluruh. Salah satu bagian dari penilaian hasil belajar adalah tes.

Sekolah masih menggunakan tes pilihan ganda sebagai alat ukur untuk menentukan keberhasilan peserta didik. Akan tetapi sekolah dalam hal ini guru-guru belum dapat menentukan kualitas dan kelayakan soal yang digunakan dengan baik. Apalagi belum banyak guru yang memahami cara menganalisa butir soal secara komputerasi. Seharusnya, sebelum sebuah soal pihan ganda dijadikan sebagai alat ukur suatu proses pembelajaran, hal yang harus dilakukan adalah menganalisis soal tersebut. Sehingga dapat ditentukan soal yang memiliki kualitas baik, soal yang harus diperbaiki, dan soal mana yang harus dibuang. Kegiatan Pelatihan menganalisis butir soal dengan komputerisasi bagi guru SMA Muhammadiyah Bangkinang ini berjalan dengan baik dan lancar. Pelatihan ini memberikan pengetahuan dan pemahaman tentang pentinganya melakukan analisis butir soal pada saat ini.

Dengan demikian penting dilakukan kegiatan ini, karena sekolah dalam hal ini guru dapat pengetahuan dan keterampilan dalam menganalisis butir soal melalui komputarisasi yaitu
\end{abstract}


menggunakan software Quest. Sehingga, ke depannya guru dengan mudah melakukan perbaikan terhadap soal-soal di sekolah.

Kata Kunci: Pengabdian kepada Masyarakat, Karya Ilmiah, Referensi, Mendeley

\section{PENDAHULUAN}

Penilaian terhadap proses pembelajaran dan penilaian terhadap hasil belajar merupakan dua hal yang sangat penting dalam pendidikan. Penilaian terhadap proses dan hasil merupakan bagian yang menyatu dengan kegiatan proses pembelajaran. Penilaian terhadap proses dan hasil pembelajaran dijadikan sebagai acuan untuk memperbaiki proses pembelajaran secara menyeluruh.

Salah satu bagian dari penilaian hasil belajar adalah tes. Tes merupakan seperangkat alat yang berisi tugas yang harus dikerjakan atau sejumlah pertanyaan yang harus dijawab oleh peserta didik untuk mengukur tingkat pemahaman dan penguasannya terhadap cakupan materi yang dipersyarakatkan, dan sesuai dengan tujuan pengajaran tertentu (Majid \& Firdaus; 2014).

Tes tertulis terdiri dari memilih atau menyuplai jawaban dan uraian. Tes pilihan ganda merupakan salah satu bagian dari tes yang menilai kemampuan mengingat dan memahami. Tes pilihan ganda masih dijadikan sekolah sebagai alat ukur untuk menentukan keberhasilan peserta didik di sekolah. Permasalahannya adalah apakah soal yang digunakan sekolah itu memiliki kualitas yang baik dan layak digunakan atau tidak. Karena bisa jadi soal yang digunakan secara analisa tidak layak akan tetapi karena pihak sekolah tidak mengetahuinya masih saja digunakan sebagai alat ukur keberhasilan peserta didik di sekolah.

Menganalisa butir soal merupakan suatu kegiatan yang harus dilakukan oleh guru untuk mendapatkan kualitas soal yang dibuat lebih baik dan layak digunakan. Tujuan penganalisaan soal adalah untuk mengkaji dan menentukan setiap butir soal agar didapatkan soal yang memiliki kualitas yang baik. Selain itu juga dapat meningkatkan kualitas tes melalui revisi soal yang tidak efektif serta menentukan apakah siswa sudah memahami materi yang telah diajarkan (Aiken, 1994: 63).

Soal yang memiliki kualitas yang baik adalah soal yang memberikan informasi yang tepat sesuai dengan tujuan dibuatnya soal. Anastasi dan Urbina 1997: 72, mengatakan dalam melaksanaaknan alisis butir soal, para penulis soal dapat menganalisa secara kualitatif dalam kaitan isi dan bentuknya, dan kuantitatif dalam kaitan dengan ciri-ciri statistiknya.

Analisa kualitatif dapat berupa validitas isi dan konstruk, sedangkan analisa kuantitatif dapat berupa pengukuran tingkat kesukaran soal dan diskriminasi soal yang termasuk validitas soal dan reliabilitasnya.

Manfaat Menganalisa Soal (Nitko, 1996: 308-309) : (1) menentukan apakah suatu fungsi butir soal sesuai dengan yang diharapkan, (2) memberi masukan kepada siswa tentang kemampuan dan sebagai dasar untuk bahan diskusi di kelas, (3) memberi masukan kepada guru tentang kesulitan siswa, (4) memberi masukan pada aspek tertentu untuk pengembangan kurikulum, (5) merevisi materi yang dinilai atau diukur, (6) meningkatkan keterampilan penulisan soal.

Sekolah masih menggunakan tes pilihan ganda sebagai alat ukur untuk menentukan keberhasilan peserta didik. Akan tetapi sekolah dalam hal ini guruguru belum dapat menentukan kualitas dan kelayakan soal yang digunakan 
dengan baik. Apalagi belum banyak guru yang memahami cara menganalisa butir soal secara komputerasi. Seharusnya, sebelum sebuah soal pihan ganda dijadikan sebagai alat ukur suatu proses pembelajaran, hal yang harus dilakukan adalah menganalisis soal tersebut. Sehingga dapat ditentukan soal yang memiliki kualitas baik, soal yang harus diperbaiki, dan soal mana yang harus dibuang.

SMA Muhammadiyah Bangkinang merupakan salah satu sekolah yang mengadakan ulangan dan ujian dengan menggunakan soal pilihan ganda. Akan tetapi guru-guru di SMA Muhammadiyah Bangkinang belum bisa sepenuhnya menentukan kualitas soal yang layak digunakan. Oleh karena itu perlu diberikan pelatihan kepada guruguru cara menganalisa tes butir soal. Sehingga dihasilkan kualitas soal yang baik dan menghasilkan keluaran proses pembelajaran yang juga berkualitas.

\section{METODE PENGABDIAN}

Dalam Kegiatan Pengabdian ini materi pelatihan ini adalah berkaitan dengan konsep penilaian dan analisis butir soal (lampiran 3). Sedangkan metode dalam pelaksanaan kegiatan ini dilakukan melalui ceramah, pendekatan diskusi kelompok terarah (FGD) dan evaluasi. Metode ceramah digunakan pemateri untuk menyampaikan materi dengan power point selama beberapa menit dan dilanjutkan dengan simulasi penganalisaan tes butir soal secara komputerasi oleh guru. Metode FGD yang digunakan supaya diskusi terfokus dari guru dengan pemateri terkait dengan materi yang sudah diberikan. Pada FGD ini diharapkan guru-guru betul-betul memahami cara menganalisa butir soal secara komputerasi dengan mandiri. Metode Evaluasi dilakukan untuk memeriksa pemahaman guru terkait dengan analisa butir soal secara komputerasi. Rancangan evaluasi terdiri atas rancangan evaluasi terhadap pelatihan yang telah dilaksanakan. Secara rinci rancangan evaluasi digambarkan pada tabel di bawah ini :

\begin{tabular}{|l|l|l|}
\hline No. & \multicolumn{1}{|c|}{$\begin{array}{c}\text { Indikator } \\
\text { Kegiatan }\end{array}$} & \multicolumn{1}{|c|}{$\begin{array}{c}\text { Tolak } \\
\text { Ukur }\end{array}$} \\
\hline 1. & $\begin{array}{l}\text { Pelaksanaan } \\
\text { pelatihan }\end{array}$ & $\begin{array}{l}\text { Sesuai } \\
\text { dengan } \\
\text { jadwal } \\
\text { yang telah } \\
\text { disepakati } \\
\text { bersama }\end{array}$ \\
\hline 2. & $\begin{array}{l}\text { Kehadiran para } \\
\text { peserta } \\
\text { pelatihan }\end{array}$ & $\begin{array}{l}\text { Jumlah } \\
\text { peserta } \\
\text { pelatihan } \\
\text { hadir } \\
\text { minimal } \\
80 \%\end{array}$ \\
\hline 3. & $\begin{array}{l}\text { Keaktifan para } \\
\text { peserta } \\
\text { pelatihan }\end{array}$ & $\begin{array}{l}\text { Peserta } \\
\text { terlihat } \\
\text { antusias } \\
\text { dan aktif } \\
\text { dalam } \\
\text { mengikuti } \\
\text { pelatihan }\end{array}$ \\
\hline
\end{tabular}

Mitra utama program PKM adalah guru SMA. Mitra ini akan terlibat penuh dalam tahapan kegiatan program PKM. Bentuk partisipasi mitra adalah:

1. Menyediakan tempat pelatihan, termasuk menyediakan proyektor.

2. Menghadirkan Guru

3. Membawa labtop yang akan digunakan untuk pelatihan

Sedangkan Universitas Muhammadiyah Riau (UMRI) menyediakan konsumsi, pemateri serta sarana transportasi darat menuju ke lokasi mitra ketika program berjalan.

\section{HASIL DAN PEMBAHASAN}

Kegiatan pelatihan menganalisa tes butir soal secara komputerasi bagi guru guru SMA Muhammadiyah Bangkinang ini telah dilaksanakan sesuai dengan jadwal yang telah disepakati oleh pihak 
sekolah SMA Muhammadiyah Bangkinang. Pengabdian kepada masyarakat ini dimulai dengan melakukan tahap persiapan, tahap ini dilakukan survey dan observasi serta izin kepada pihak sekolah sebagai tempat pelaksanaan pengabdian ini. Selain itu pada tahap persiapan juga mencari informasi jumlah peserta dan kegiatan peserta sebelum diadakannya pelatihan. Setalah waktu disepakati, selanjutnya tim Dosen Pendidikan Ilmu Pengetahuan Alam Fakultas Ilmu Keguruan dan Pendidikan Universitas Muhammadiyah Riau menyusun jadwal pelaksanaan dan membuat kesepakatan dengan pihak sekolah.

Kegiatan ini dilaksanakan dalam rangka catur dharma Perguruan Tinggi Muhammadiyah, yang salah satunya adalah pengabdian kepada masyarakat. Pelatihan ini diberikan untuk meningkatkan profesionalitas guru dalam proses belajar mengajar di kelas, khusunya berkaitan dengan proses penilaian. Selain itu juga memberikan kemudahan bagi para guru nantinya dalam menjalankan proses belajar mengajar di kelas sehingga suasana di kelas pun menjadi kondusif dan menyenangkan.

Pada saat pelaksanaan, kegiatan ini dimulai dengan tahapan persiapan, dimana tim pelaksana melakukan briefing terlebih dahulu agar kegiatan pelatihan ini terlaksana dengan baik. Kemudian tahapan pelaksanaan kegiatan ini dimulai dengan menjelaskan materi tentang perkembangan dan pentingnya menganalisa tes butir soal bagi guru yang dilaksanakan di SMA Muhammadiyah Bangkinang.

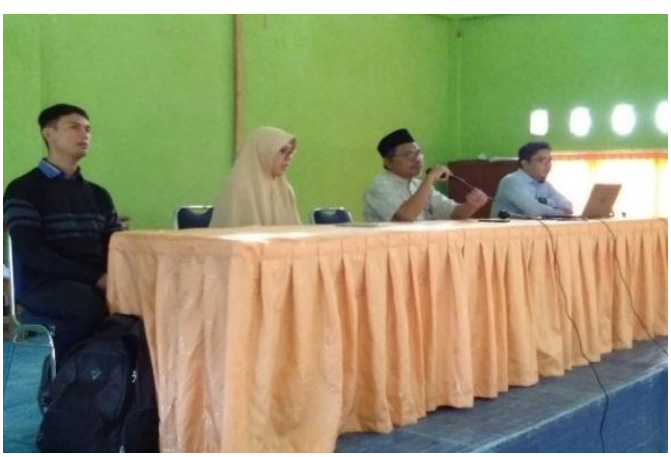

Gambar 1. Pembukaan oleh sekolah mitra

Tahapan pelatihan diberikan kepada setiap peserta berupa ceramah. Kemudian diskusi berupa tanya jawab berlangsung pada saat kegiatan sedang berlangsung. Pelatihan ini dimulai pada hari Sabtu 08 September 2018 pukul 08.30 WIB sampai selesai. Evaluasi pada tahap pertama telah sesuai dengan indikator dan rancangan evaluasi diperoleh data sebagai berikut:

1. Jumlah peserta yang hadir sebanyak kurang lebih $80 \%$ dari 33 orang guru bidang SMA Muhammadiyah Bangkinang.

2. Peserta sangat terlihat antusias dan aktif selama mengikuti kegiatan hingga akhir pelatihan selesai.

3. Peserta memahami apa yang telah disampaikan tentang pentingnya menganalisa tes butir soal bagi guru, ini terlihat dari antusiasnya peserta dengan banyaknya pertanyaan.

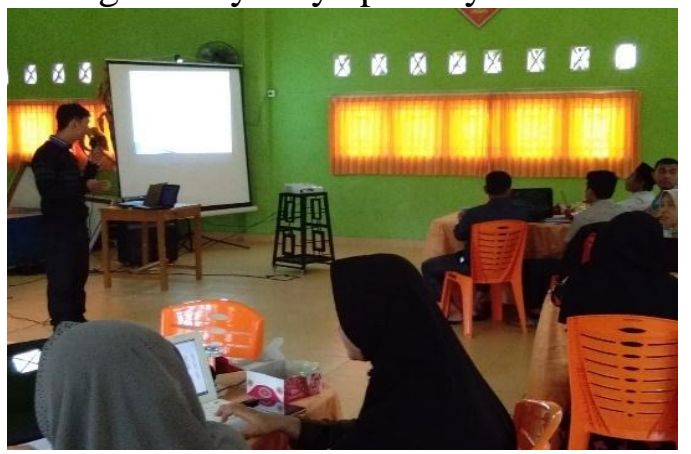

Gambar 2. Suasana Kegiatan

Evaluasi secara umum berhasil dengan baik dan memuaskan peserta maupun pembicara dam pelatihan. Peserta juga berharap ditahun gahun 
berikutnya dapat diberikan kesempatan untuk mendapatkan pelatihan sejenis.

\section{SIMPULAN}

Kegiatan Pelatihan menganalisis butir soal dengan komputerisasi bagi guru SMA Muhammadiyah Bangkinang ini berjalan dengan baik dan lancar. Pelatihan ini memberikan pengetahuan dan pemahaman tentang pentinganya melakukan analisis butir soal pada saat ini.

Pemahaman mengenai analisis butir soal dengan komputerisasi ini harus diketahui oleh para guru baik itu di tingkat sekolah maupun di tingkat perguruan tinggi (dosen) sebagai penunjang pembelajaran dikelas dan juga sekaligus upaya pengajar dalam meningkatkan profesionalitas nya sebagai pendidik di kelas.

Kegiatan ini hendaknya tidak sampai disini saja, namun harus diterapkan dan dilakukan oleh masing masing individu. Untuk berikutnya pengabdian masyarakat ini bisa dilanjutkan dengan metode lainnya di sekolah-sekolah selanjutnya. Diharapkan ke depannya guru mampu dan menjadi rutinitas dalam menganalisis butir soal di dalam proses belajar mengajar di kelas

\section{UCAPAN TERIMAKASIH}

Pelaksanaan kegiatan Pengabdian kepada Masyarakat ini tentunya tidak akan terlaksana sesuai rencana jika tanpa bantuan dari berbagai pihak. Oleh karena itu maka penulis mengucapkan terima kasih kepada seluruh pihak yang telah membantu secara materil dan moril sehingga kegiatan pengabdian ini dapat terlaksana dengan baik. Adapun ucapan terima kasih tersebut ditujukan kepada:

1. Rektor UMRI

2. Ketua LPPM UMRI

3. Dekan FKIP UMRI

4. Ketua Program Studi Pendidikan

Ilmu Pengetahuan Alam
5. Kepala SMA Muhammadiyah Bangkinang

6. Majelis Guru SMA Muhammadiyah Bangkinang

\section{DAFTAR PUSTAKA}

[1] Abdul Majid, (2015). Penilaian Autentik Proses Dan Hasil Belajar, PT Remaja Rosdakarya, Bandung.

[2] Abdul Majid, Aep S. Firdaus, (2014). Penilaian Autentik Proses Dan Hasil Belajar, Interes Media, Bandung.

[3] Aiken, Lewis R. (1994). Psychological Testing and Assessment,(Eight Edition). Boston: Allyn and Bacon.

[4] Anastasi, Urbina (1997). Psycological Testing (7th Ed), New Jersey: Prentice-Hall, Inc.

[5] Nitko, Anthony J. (1996). Educational Assessment of Students, Second Edition. Ohio: Merrill an imprint of Prentice Hall Englewood Cliffs. 